\title{
ENERGY METABOLISM OF THE NORMAL AND CRYPTORCHID RAT TESTIS
}

\author{
MATTI HÄRKÖNEN AND MARTTI KORMANO \\ Department of Clinical Chemistry and Department of Anatomy, \\ University of Helsinki, Helsinki, Finland
}

(Received 18th May 1970)

\begin{abstract}
Summary. The concentrations of glycogen, glucose, ATP, glucose-6phosphate and lactate were studied in normal and cryptorchid rat testes using enzymatic pyridine nucleotide methods. With the exception of ATP, all the substrates were significantly higher in the cryptorchid testes. The decrease of the energy metabolites and the accumulation of lactate were also studied in testes incubated in the absence of $\mathrm{O}_{2}$ at the temperatures of $33.6^{\circ} \mathrm{C}$ and $36.6^{\circ} \mathrm{C}$. The metabolic rate of the incubated organs was estimated in terms of the rate of use of high energy phosphate $(\sim \mathrm{P})$ calculated from changes in ATP, glucose and glycogen. A good parallelism between hexose utilization and lactate production was observed in both normal and cryptorchid testes. A rapid mobilization of glycogen, suggesting activation of phosphorylase, was observed in incubated cryptorchid testes. The calculated oxygen consumption of cryptorchid testes was about $100 \%$ higher than that of the normal testes at the same temperature. It is suggested that the basic metabolic rate of the interstitial tissue is higher than that of the seminiferous tubules.
\end{abstract}

\section{INTRODUCTION}

The present knowledge of the energy metabolism of the rat testis is limited and is based mainly on the results of studies in vitro on testicular slices and homogenates. Such studies have suggested that glucose is the major fuel of the testis (Himwich \& Nahum, 1929; Dickens \& Simer, 1930, 1931), and that there exists an active pentose phosphate cycle (Bloom, 1955; Field, Pastan, Herring \& Johnson, 1960; Free, Gruz, Johnson \& Gomes, 1968).

Experiments in vivo on the oxidative metabolism of the testis have been performed mainly on larger animals, especially on the ram (Annison, Scott \& Waites, 1963; Setchell \& Waites, 1964; Setchell \& Hinks, 1967) but no relevant work has been published on the rat testis.

Both biochemical (Rudolph \& Olsen, 1956; Schor, Gara \& Perez, 1963) and histochemical (Niemi \& Ikonen, 1962; Kormano, Härkönen \& Kontinen, 1964) methods have been used to study the enzymes which function in known pathways of glucose metabolism and there is evidence on the basis of these findings that the seminiferous tubules and the interstitial tissue have a 
qualitatively different type of metabolism. Metabolic studies on testes with atrophied tubules have led to a similar conclusion (Tepperman, Tepperman \& Dick, 1949; Paul, Paul, Kopko, Bender \& Everett, 1953; Steinberger \& Wagner, 1961), but little attention has been paid to the substrates of the energy metabolism in normal or atrophied testes.

The testes will maintain function for a very short time through utilization of endogenous energy reserves, when incubated under $\mathrm{N}_{2}$ in a closed system. In the absence of oxygen, this reserve has three major components: glycogen, glucose and ATP. Determination of these substrates offers an opportunity for studying the testicular energy metabolism of a small animal like the rat. Using testes with normal and atrophied tubules, differences in the metabolism of the tubules and the interstitial tissue will influence the result and give evidence of the metabolic characteristics of these two tissues. In the present study, measurements have been made of the major energy-yielding metabolites in the normal and experimentally cryptorchid rat testis.

\section{EXPERIMENTAL}

Animals

Adult, male, white rats of the Sprague-Dawley strain were used. For normal material, testes of thirteen 6-month-old rats were used. Ten rats were rendered cryptorchid at the age of $2 \frac{1}{2}$ months by displacement of both testes into the abdominal cavity, invagination of the processus vaginalis and closure of the deep inguinal ring. These animals were studied 6 weeks later, together with twelve controls.

\section{Preparation of material}

Thirty minutes after injection of pentobarbitone (Nembutal, Abbot, 50 $\mathrm{mg} / \mathrm{kg}$ ), the testes were exposed through a midline incision in the lower abdomen, rapidly excised and frozen in Freon $12\left(\mathrm{CGl}_{2} \mathrm{~F}_{2}\right)$ chilled to the freezing point $\left(-150^{\circ} \mathrm{C}\right)$ with liquid nitrogen.

In incubation experiments, the excised normal testes were incubated either at $36.6^{\circ} \mathrm{G}$ (inguinal temperature) or $33.6^{\circ} \mathrm{G}$ (rat normal testicular temperature; Kormano, 1967) for various intervals in mineral oil through which $\mathrm{N}_{2}$ was bubbled. Cryptorchid testes were incubated only at $36 \cdot 6^{\circ} \mathrm{C}$.

The time interval between the excision of the organ and freezing or beginning of incubation was 2 to $3 \mathrm{sec}$.

\section{Analytical methods}

The frozen samples were stored at $-75^{\circ} \mathrm{C}$ until ready for analysis. Acid extracts were prepared by adaptation of the procedure of Nelson, Lowry \& Passonneau (1966) from approximately $100 \mathrm{mg}$ of tissue weighed in a cold room at $-20^{\circ} \mathrm{C}$. A detailed description of the procedure has been given in an earlier paper (Härkönen, Palkama \& Laasonen, 1968). Glycogen was measured from separate samples after alkaline digestion and ethanol precipitation (Good, Kramer \& Somogyi, 1933). The glycogen, glucose, glucose-6-phosphate, ATP and lactate were determined with enzymatic pyridine nucleotide methods as 
previously described by Lowry, Passonneau, Hasselberger \& Schulz (1964), with minor modifications (Härkönen et al., 1968). In a statistical analysis of the results, the $t$ test was employed according to the method of Jonge (1964).

\section{RESULTS}

\section{Normal values}

The concentrations of glycogen, glucose and lactate were rather low when compared with some other tissues (Härkönen, Passonneau \& Lowry, 1969). The concentration of ATP was relatively high. The concentrations of metabolites and calculated high energy phosphate $(\sim \mathrm{P})$ in the testes of different experimental groups are presented in Table 1. With the exception of ATP, all

TABLE 1

THE CONCENTRATION OF VARIOUS SUBSTRATES OF THE ENERGY METABOLISM IN NORMAL AND CRYPTORCHID TESTES

\begin{tabular}{|c|c|c|c|}
\hline \multirow[t]{2}{*}{ Metabolite } & \multirow{2}{*}{$\frac{\begin{array}{c}\text { Normal testis* } \\
\text { mmol/kg wet wt }\end{array}}{\text { Mean } \pm \text { S.E. }}$} & \multicolumn{2}{|c|}{$\begin{array}{l}\text { Cryptorchid testis } \dagger \\
\text { mmol/kg wet wt }\end{array}$} \\
\hline & & Mean \pm S.E. & $\mathbf{P}<$ \\
\hline $\begin{array}{l}\text { Glycogen } \\
\text { Glucose } \\
\text { Glucose-6-phosphate } \\
\text { ATP } \\
\text { Lactate } \\
\sim \text { P }\end{array}$ & $\begin{array}{l}0.41 \pm 0.04 \\
0.66 \pm 0.05 \\
0.036 \pm 0.002 \\
2.46 \pm 0.05 \\
0.95 \pm 0.07 \\
7.42 \pm 0.15\end{array}$ & $\begin{array}{c}1.43 \pm 0.08 \\
3.13 \pm 0.27 \\
0.141 \pm 0.014 \\
1.39 \pm 0.16 \\
4.41 \pm 0.39 \\
13.18 \pm 0.46\end{array}$ & $\begin{array}{l}0.001 \\
0.01 \\
0.01 \\
0.01 \\
0.01 \\
0.001\end{array}$ \\
\hline
\end{tabular}

the other substrates were significantly higher in the cryptorchid testes. In addition, the concentration seemed to be slightly higher in the younger group of control animals.

\section{Incubation experiments}

Incubation of normal testes for $30 \mathrm{sec}$ at the physiological temperature of the rat testis $\left(33.6^{\circ} \mathbf{G}\right)$, and at a higher temperature $\left(36.6^{\circ} \mathbf{G}\right)$ caused a rapid decrease in the glucose-6-phosphate concentration. After an incubation time of $1 \mathrm{~min}$ at $33.6^{\circ} \mathrm{C}$, no significant decrease of the other substrate concentrations occurred but at $36.6^{\circ} \mathrm{C}$, a marked lowering of A'TP concentration was seen. Throughout the incubation experiments, the decrease of substrate concentrations differed only little in the testes incubated at the two different temperatures. The level of glycogen and glucose decreased to half in about $5 \mathrm{~min}$ at both temperatures and a half of both ATP and glucose-6-phosphate was utilized within about $1 \mathrm{~min}$ and $30 \mathrm{sec}$, respectively, at both temperatures (Text-figs. 1 and 2).

The experimentally cryptorchid testes behaved in a very different way during the incubation experiments, when compared with the control testes incubated at the same temperature of $36 \cdot 6^{\circ} \mathrm{G}$. The concentration of glycogen, which decreased only slowly in the normal testes, decreased from the high 


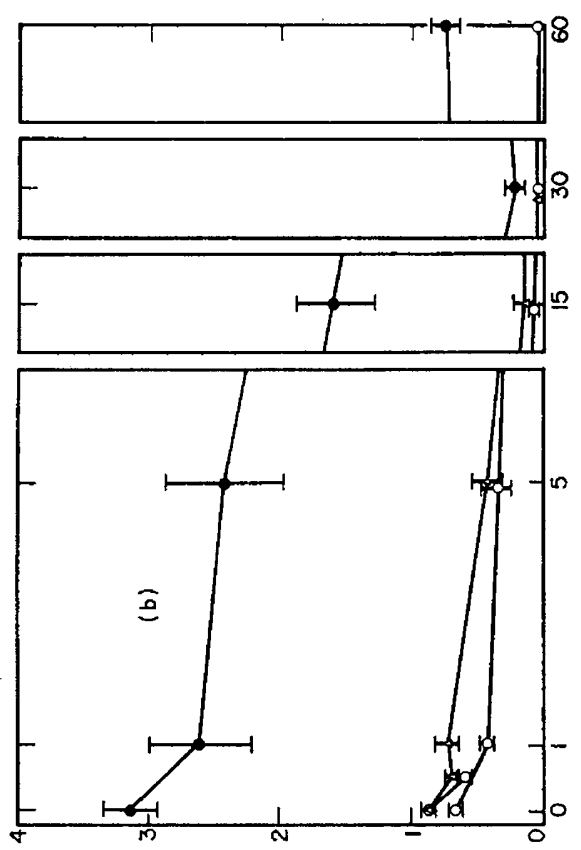

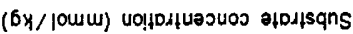

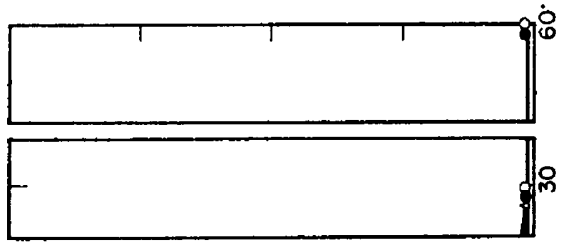

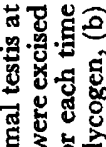

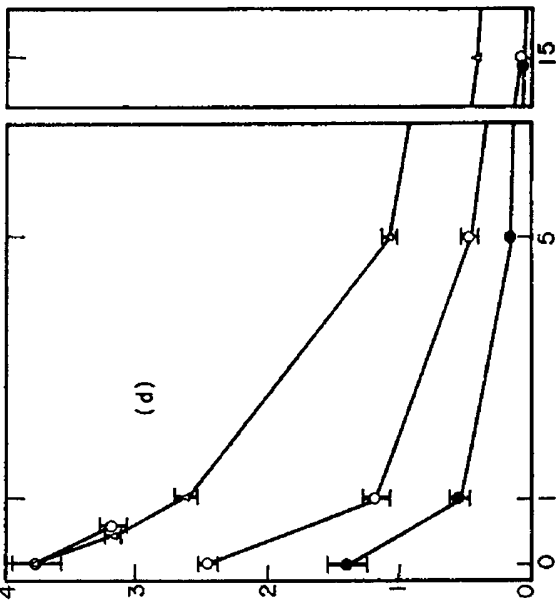

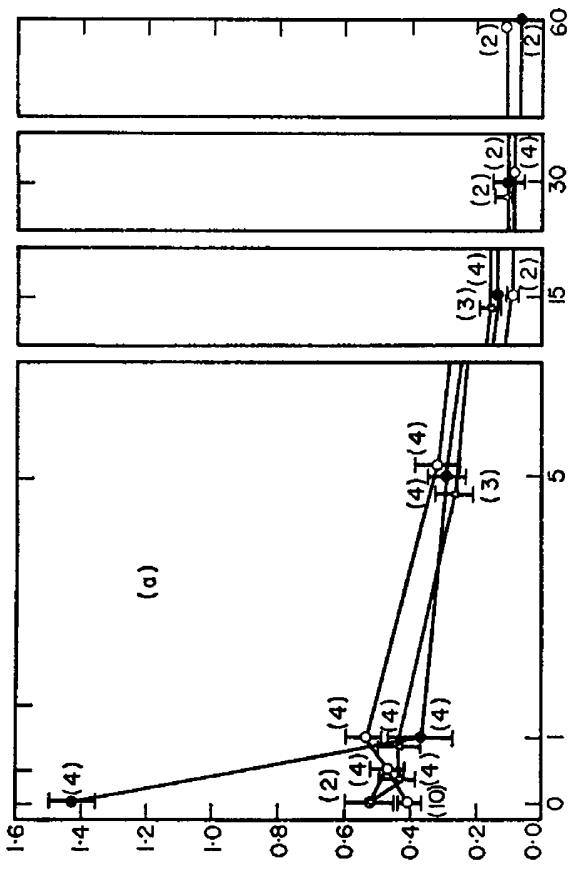

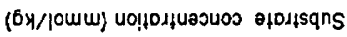

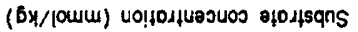
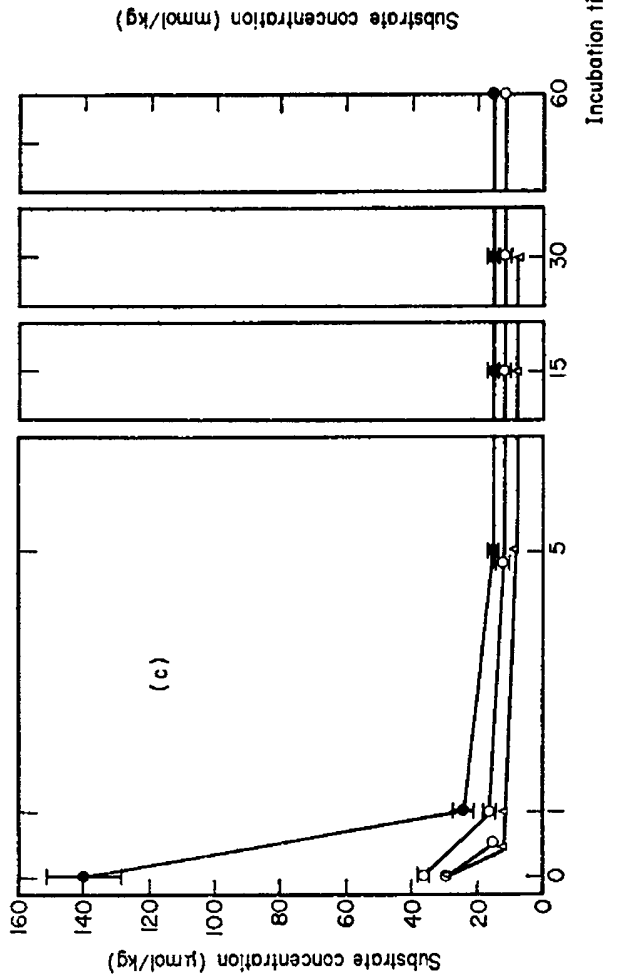

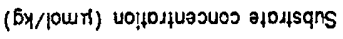




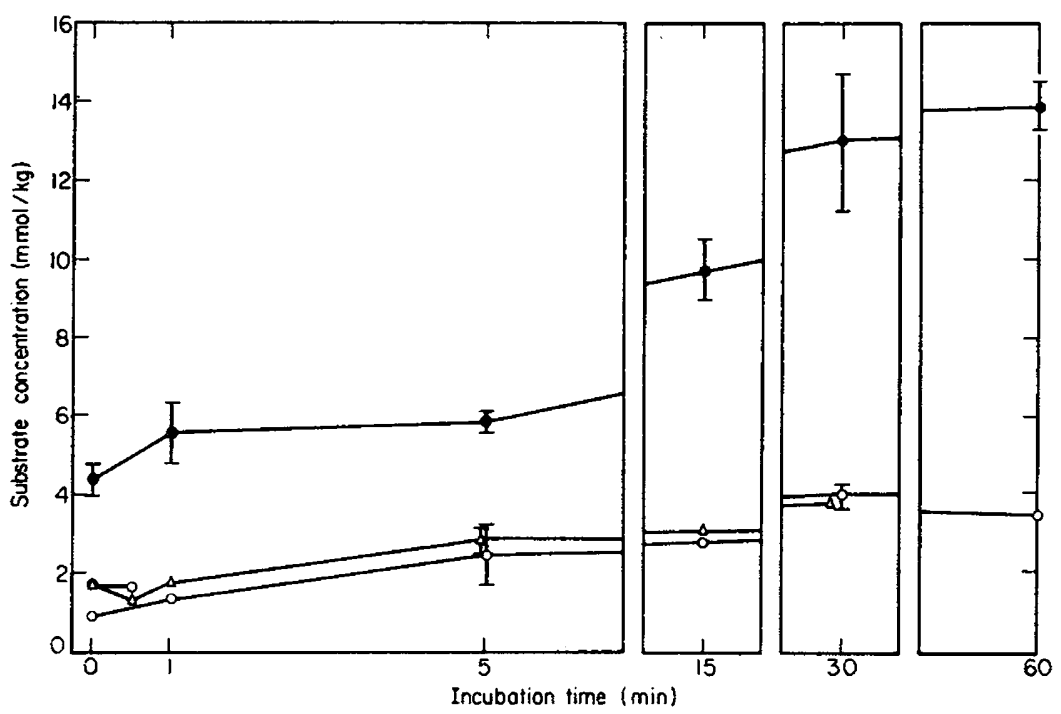

TEXT-FIG. 2. Production of lactate by normal and cryptorchid rat testis when incubated in the absence of oxygen. The testes and the representation are the same as for Text-fig. 1 .

initial value to one fourth of the value within $1 \mathrm{~min}$. The levels of glucose-6phosphate and ATP presented a very rapid decrease to half the original concentration within less than $30 \mathrm{sec}$. The initial level of glucose was much higher in the cryptorchid testes and the $50 \%$ value was attained only after $15 \mathrm{~min}$ instead of $5 \mathrm{~min}$ in the normal testes.

The rates of hexose utilization and lactate production were very similar in the normal testes at both incubation temperatures (Text-fig. 3). At $33.6^{\circ} \mathrm{C}$,

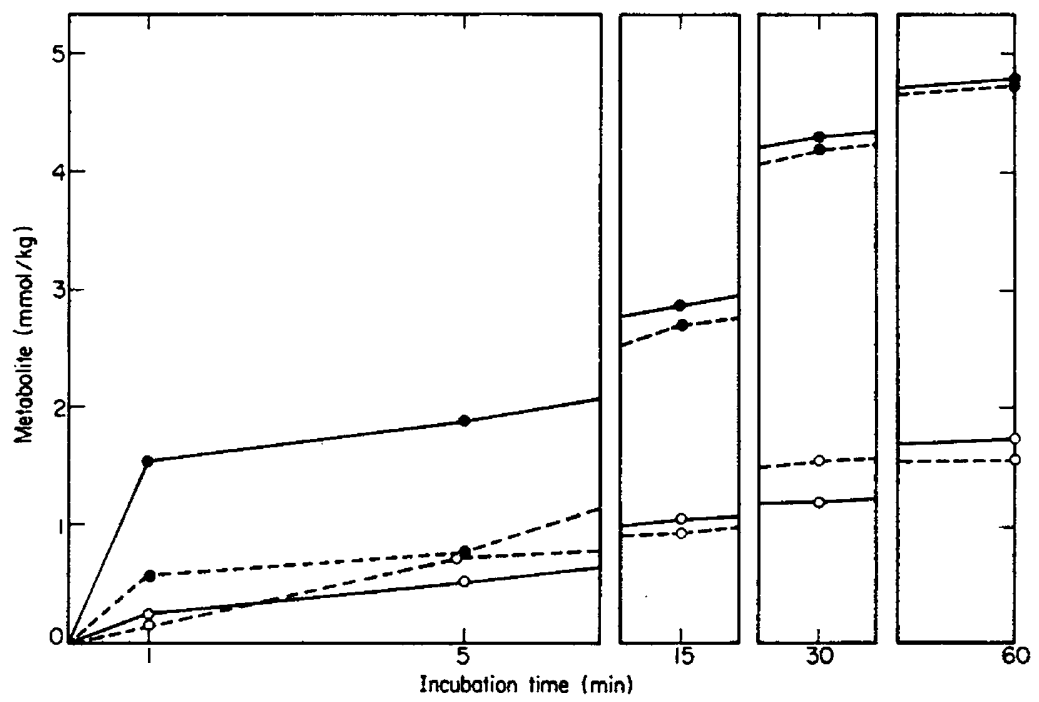

TexT-pIG. 3. Utilization of hexose (glycogen + glucose) and accumulation of lactate by normal and cryptorchid rat testis when incubated in the absence of oxygen. $0-0$, Hexose, normal testis at $36 \cdot 6^{\circ} \mathbf{C} ; 0---0$, $\frac{1}{2}$ lactate, normal testis at $36.6^{\circ} \mathbf{C}$; $-\bullet$, hexose, cryptorchid testis at $36 \cdot 6^{\circ} \mathrm{C}$; $---\bullet$, $\frac{1}{2}$ lactate, cryptorchid testis at $36 \cdot 6^{\circ} \mathrm{C}$. The testes and the representation are the same as for Text-fig. 1. 
there was a slight initial lag of lactate production at $1 \mathrm{~min}$ but later, the increase in lactate concentration accompanied the decrease in glucose and glycogen. At the incubation temperature of $36.6^{\circ} \mathrm{G}$, the lag of lactate production lasted only $30 \mathrm{sec}$. In cryptorchid testes, production of lactate was seen to lag behind during the first $5 \mathrm{~min}$ but, later, hexose utilization and lactate production were observed in parallel in the testes.

An approximation of the testicular metabolic rate can be calculated in the terms of the rate of the use of high energy phosphate $(\sim P)$ from the changes in ATP, glucose and glycogen. In the absence of $\mathrm{O}_{2}$, each mol of glucose converted to lactate produces $2 \mathrm{~mol}$ of $\sim \mathrm{P}$. Each mol of glycogen converted to lactate produces 2.9 equivalents of $\sim \mathrm{P}$, assuming a $10 \%$ branching in the glycogen molecule. ATP gives 2 equivalents of $\sim$ P. In the presence of $\mathrm{O}_{2}$, for each $\mathrm{mol}$ of glucose oxidized to $\mathrm{CO}_{2}$, there is believed to be a yield of 38 equivalents of

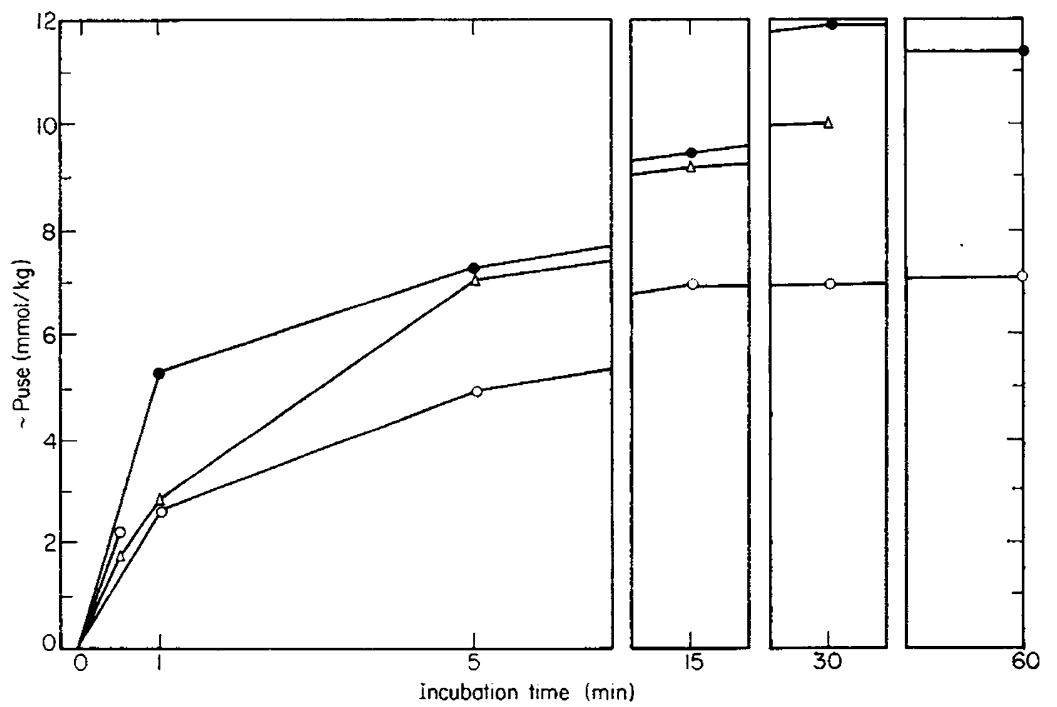

TexT-FIG. 4. Calculated use of high energy phosphate $(\sim P)$ in normal and cryptorchid rat testis during anoxic incubation. The ordinate represents the sum of $\sim \mathrm{P}$ derived from ATP, glucose and glycogen. $O$, Normal testis at $36 \cdot 6^{\circ} \mathrm{C} ; \Delta$, normal testis at $33 \cdot 6^{\circ} \mathrm{C}$; $\bullet$, cryptorchid testis at $36^{\circ} 6^{\circ} \mathrm{C}$.

$\sim P$ (i.e. an average $P: O$ ratio of $3 \cdot 2$ ). At the incubation temperature of $33.6^{\circ} \mathrm{C}$, a lower utilization of $\sim \mathrm{P}$ by a normal rat testis was seen for the first $30 \mathrm{sec}$ than at $36 \cdot 6^{\circ} \mathrm{C}$. During the first minute of incubation, however, the use of $\sim \mathrm{P}$ was approximately the same in both groups, and at $5 \mathrm{~min}$, the total amount used was near the exhaustion of the store. The cryptorchid testes were seen to utilize $\sim \mathrm{P}$ at $36 \cdot 6^{\circ} \mathrm{G}$, at a rate which was twice as high as that of the normal testes. The amount utilized within $1 \mathrm{~min}$ was used as a basis for determination of the metabolic rate, because the testis is a relatively large organ and its initial oxygen content may influence the result considerably during the first few seconds. On the other hand, the value obtained for the cryptorchid testis is probably too low because of its very high initial consumption of $\sim \mathrm{P}$, which nears the limits of exhaustion within 1 min (Text-fig. 4).

At the temperatures of $33.6^{\circ} \mathrm{G}$ and $36.6^{\circ} \mathrm{C}$, the rates of use of $\sim \mathrm{P}$ during 
the first minute of anoxia were 173 and $160 \mathrm{mmol} \mathrm{kg}{ }^{-1} \mathrm{hr}^{-1}$, respectively, in the normal testis. On the basis of a $\mathrm{P}: \mathrm{O}$ ratio of $3 \cdot 2$, this rate of $\sim \mathrm{P}$ used is equivalent to an $\mathrm{O}_{2}$ consumption of 27 and $25 \mathrm{mmol} \mathrm{kg} \mathrm{kg}^{-1} \mathrm{hr}^{-1}$, respectively. The cryptorchid testes consumed $318 \mathrm{mmol} \sim \mathrm{P} \mathrm{kg}^{-1} \mathrm{hr}^{-1}$, which is equivalent to an oxygen consumption of $50 \mathrm{mmol} \mathrm{kg}{ }^{-1} \mathrm{hr}^{-1}$.

\section{DISGUSSION}

The seminiferous tubules and the interstitial tissue form two metabolically different tissue blocks, separated by the tubular supporting structures, which actively regulate the biochemical composition of extracellular fluid within the tubules (Setchell, Voglmayr \& Waites, 1969). The net metabolic pattern and an experimentally induced change in this pattern may be the result of changes in the cellular composition or changes in the metabolic activity of the various cells themselves. The results of a biochemical study of the whole testis tissue have to be interpreted in the light of these relationships. In addition, pentobarbitone anaesthesia is known to depress the utilization of glucose by the testis (Setchell \& Hinks, 1967) as well as by other parts of the body (Lowry et al., 1964).

\section{Pattern of recruitment of energy stores}

The Sertoli cells contain the bulk of cytochemically demonstrable glycogen in the seminiferous tubules, both in normal (Fouquet \& Guha, 1969) and in damaged tubules (Fabbrini, Re \& Spera, 1969). The high increase of glycogen content may partially result from degeneration of those tubular cells which contain less glycogen.

The normal testis contained relatively little glucose when compared with the atrophic testis. The seminiferous tubules have a poor blood supply which inevitably results in a lower content of glucose than in the vascular interstitial tissue. There is no evidence of an increase in the permeability of the tubular wall in this condition (Kormano, 1968). Therefore, the relative increase in interstitial tissue and shrinkage of seminiferous tubules, seems to be responsible for the increased average glucose concentration of the whole organ. Another type of testicular damage, e.g. acute cadmium injury, does seem to increase the permeability of the tubular wall to glucose and consequently causes an increase in the average glucose concentration (Härkönen \& Kormano, 1970). The ATP concentration of the normal testis was seen to be relatively high, approaching that of the nervous tissue (Lowry et al., 1964). Considerable amounts of ATP have been demonstrated in spermatozoa and the compound is known to be related to sperm motility (Mann, 1964). This metabolite is probably largely formed during the late stages of spermatogenesis (Dawson, 1958). The decrease in the ATP content of cryptorchid testes may simply be a reflection of the disappearance of the more mature spermatogenic cells.

Lactate is known to be rapidly oxidized by the rat testis in vitro (Elliott, Greig \& Benoy, 1937). Experiments in vivo on ram testis have also demonstrated that very little lactate is secreted into the venous blood of the testis (Waites \& Setchell, 1964). Naturally cryptorchid ram testes, like the experimentally 
cryptorchid rat testes in the present study, have a higher content of lactic acid than the scrotal organs (Blackshaw \& Samisoni, 1967).

\section{Metabolic differences between normal and cryptorchid testes}

During incubation at two different temperatures, normal testes followed a similar pattern in the utilization of substrates, except for a slightly greater initial rate at the beginning of incubation at the higher temperature. The accumulation of lactate in anaerobic conditions followed closely the amount of hexose consumed. In cryptorchid testes, the glucose concentration decreased less rapidly than in the control testes and instead, a rapid mobilization of glycogen was seen. This suggests that there is an increased phosphorylase activity in the cryptorchid rat testis. As estimated histochemically, phosphorylase, both active and total, is confined to the seminiferous tubules and the rete testis (Guha \& Wegmann, 1966). From the illustrations provided by these authors, it can be assumed that the localization of highest activity is in the Sertoli cells. Numerous other enzyme activities show a high increase histochemically in the tubular side of the rat testis (Kormano et al., 1964), and it can be assumed that phosphorylase of Sertoli cells may be responsible for the very high activity in cryptorchid testes.

Gonadotrophins have been reported to increase the endogenous respiration of testis tissue and rat interstitial cells in vitro (Steinberger \& Wagner, 1961; Hamberger \& Steward, 1968), and to cause accumulation of cyclic AMP, which precedes the increase in hormone synthesis (Kuehl, Patanelli, Tarnoff \& Humes, 1970). Since cyclic AMP, which seems to be a mediator of the hormonal activity, is also known to activate phosphorylase, one might also expect an increased phosphorylase activity in cryptorchid testes. Further evaluation of these factors will require more detailed studies, but it is interesting to note that in the hamster, testicular phosphorylase activity increases progressively during puberty (Fouquet \& Guha, 1969). Fabbrini et al. (1969) have obtained histochemical evidence that in human testes with 'idiopathic' germinal cell aplasia, Sertoli cells may be congenitally lacking in glycogen and related enzymes but that in acquired germinal cell aplasia, a large amount of glycogen is present.

Glucose is the major energy substrate in both normal and cryptorchid testes, but there are different opinions on the effect of heat damage on glucose catabolism. The data of Hollinger \& Davis (1968) and Free, Massie \& VanDemark (1969) suggest that the overall oxidative catabolism of glucose is markedly reduced in cryptorchid rat testis and this is taken to reflect the absence of more mature germinal cells. In the conscious ram, Waites \& Setchell (1964) observed an inconstant increase of glucose uptake by heated testes, but no change in the lactate concentration of the spermatic vein blood. In the aerobic incubation experiments of Hollinger \& Davis (1968), cryptorchidism resulted in an increase in testicular protein labelling by radioactive glucose and impairment of glucose catabolism to perchloric-acid-soluble intermediates, among which lactate predominates.

The observations in vitro on the rat and ram testis agree with each other in that aerobically there is little change in the accumulation of lactate as a result of cryptorchidism, but anaerobic glycolysis is stimulated in the cryptorchid organ. 
An elevation of $3^{\circ} \mathrm{C}$ in the incubation temperature will not immediately increase the internal temperature of the testis. This is certainly partially responsible for the small difference in the results between the two incubation temperatures. Waites \& Setchell (1964) observed a 70\% increase in the $\mathrm{O}_{2}$ uptake of testes of conscious rams as a result of a $3^{\circ} \mathrm{C}$ rise in testicular temperature. Our numerical values for $\mathrm{O}_{2}$ uptake (25 and $27 \mathrm{mmol} \mathrm{kg}{ }^{-1} \mathrm{hr}^{-1}$ ) are comparable with the observations made by Waites \& Setchell, who observed a consumption of 13.2 to $16.2 \mathrm{mmol} \mathrm{kg}^{-1} \mathrm{hr}^{-1}$ in a testis of a conscious ram at $34^{\circ} \mathrm{C}$ in vivo, and at a temperature of $37^{\circ} \mathrm{C}$ or more, they obtained a value of $22.0 \mathrm{mmol} \mathrm{kg}{ }^{-1} \mathrm{hr}^{-1}$. The $\mathrm{O}_{2}$ consumption of the cryptorchid testis was seen to be about $100 \%$ higher than that of the normal testis at the same temperature. In the absence of added substrate, numerous authors have shown the elevation of the metabolic rate of the cryptorchid testis (Tepperman et al., 1949). As a result of studies in vitro with cryptorchid rabbit testes, VanDemark \& Ewing (1963) and Ewing \& VanDemark (1963a, b) suggested that spermatogenic arrest, which results from exposure of the testis to elevated temperatures, may be caused by reduced levels of substrate in the tissue due to a fall in blood flow. The present results show that, with the exception of ATP, cryptorchid testes contained more substrates than normal testes. Our observations agree better with the suggestion of Waites \& Setchell (1964) and Setchell, Waites \& Thorburn (1966), that at least part of the testicular damage caused by heat in vivo may be due to hypoxia induced by an increase in $\mathrm{O}_{2}$ consumption without a corresponding increase in the testicular blood flow. The rat testicular blood flow is little influenced by temperature elevation (Glover, 1966; Setchell et al., 1969) and this results in severe hypoxia in the avascular seminiferous tubules.

The $100 \%$ difference between $\mathrm{O}_{2}$ consumption by the normal and cryptorchid testis at the same temperature cannot be without significance. It may partly be due to hypophysial stimulation of the testicular cells which causes increased metabolic rate (Steinberger \& Wagner, 1961). This possibility is supported by the observations of Hamberger \& Steward (1968), who observed a $188 \%$ increase in the respiration of isolated Leydig cells as a result of stimulation with LH. Such a maximal stimulation in the present experiment seems improbable. Instead, when the $\mathrm{O}_{2}$ consumptions of the normal rat testis $(4 \cdot 3 \mu \mathrm{l}$ $\mathrm{mg}^{-1} \mathrm{hr}^{-1}$ dry weight, Steinberger \& Wagner, 1961) and the isolated interstitial-cell tissue, not subjected to hormone stimulation $\left(7.28\right.$ to $17.99 \mu \mathrm{mg}^{-1}$ $\mathrm{hr}^{-1}$ dry weight, Hamberger \& Steward, 1968) are compared, the higher basic metabolic rate of the interstitial tissue seems probable, though the opposite has also been suggested (Karjalainen \& Niemi, 1969). Experiments are now in progress to demonstrate these possible differences.

\section{ACKNOWLEDGMENTS}

The present study has been supported by grants from The National Research Gouncil for Medical Sciences, Finland, and from The Sigrid Jusélius Foundation, Helsinki, Finland. 


\section{REFERENCES}

Annison, E. F., Scott, T. W. \& Wartes, G. M. H. (1963) The role of glucose and acetate in the oxidative metabolism of the testis and epididymis of the ram. Biochem. F. 88, 482.

Blackshaw, A. W. \& Samisoni, J. I. (1967) The testes of the cryptorchid ram. Res. vet. Sci. 8, 187.

BLoom, B. (1955) Catabolism of glucose by mammalian tissues. Proc. Soc. exp. Biol. Med. 88, 317.

Dawson, R. M. C. (1958) The labelling of ram semen in vivo with radioactive phosphate and (carboxy- $\left.{ }^{14} \mathrm{C}\right)$ stearic acid. Biochem. $\mathbf{7 . 6 8 , 5 1 2 .}$

Dickens, F. \& Simer, F. (1930) The metabolism of normal and tumour tissue. II. The respiratory quotient and the relationship of respiration to glycolysis. Biochem. F. 24, 1301.

Dickens, F. \& Simer, F. (1931) The metabolism of normal and tumour tissue. IV. The respiratory quotient in biocarbonate-media. Biochem. F. 25, 985.

Elimott, K. A. C., Greig, M. E. \& Benoy, M. P. (1937) The metabolism of lactic and pyruvic acids in normal and tumour tissues. III. Rat liver, brain and testis. Biochem. F. 31, 1003.

Ewing, L. L. \& VanDemark, N. L. (1963a) Factors affecting testicular metabolism and function. II. Effect of temperature elevation in vivo on subsequent metabolic activity of rabbit testicular tissue in vitro. F. Reprod. Fert. $6,9$.

Ewing, L. L. \& VanDemark, N. L. (1963b) Factors affecting testicular metabolism and function. III. Effect of in vitro temperature elevation on tissue slices and perfused testes in the rabbit. $\mathcal{J}$. Reprod. Fert. 6, 17.

Fabbrini, A., Re, M. \& Spera, G. (1969) Behaviour of glycogen and related enzymes in the Sertoli cell syndrome. Experientia, 25, 647.

Field, J. B., Pastan, I., Herring, B. \& Johnson, P. (1960) Studies of pathways of glucose metabolism of endocrine tissues. Endocrinology, 67, 801.

Fouquet, J.-P. \& GuHA, S. (1969) Glycogen, phosphorylase and glycogen synthetase in hamster testis during postnatal development. F. Reprod. Fert. 19, 455.

Free, M. J., Cruz, N. G. V., Johnson, A. D. \& Gomes, W. R. (1968) Metabolism of glucose-1 ${ }^{14}$ C and glucose-6- $-{ }^{14} \mathrm{C}$ by testis tissue from cryptorchid and testosterone propionate treated rabbits. Endocrinology, 82, 183.

Free, M. J., Massie, E. D. \& VanDemark, N. L. (1969) Glucose metabolism by the cryptorchid rat testis. Biol. Reprod. 1, 354.

Glover, T. D. (1966) The influence of temperature on flow of blood in the testis and scrotum of rats. Proc. R. Soc. Med. 59, 765.

Goon, C. A., Kramer, H. \& Somogxi, M. (1933) The determination of glycogen. F. biol. Chem. 100, 485.

Guha, S. \& Wegmann, R. (1966) Activité phosphorylasique dans le testicule et dans l'épididyme de cobaye, avant et après la maturation sexuelle. Annls Histochim. 11, 213.

HAMBerger, L. A. \& Steward, V. W. (1968) Action of gonadotrophins in vitro on the respiration of isolated interstitial cells from the testis of the rat. Endocrinology, 83, 855 .

Härkönen, M. \& Kormano, M. (1970) Acute cadmium-induced changes in the energy metabolism of the rat testis. F. Reprod. Fert. 21, 221.

HÄrkönen, M., Palkama, A. \& LAaAsonen, L. (1968) Effect of ethanol administration and nutritional state on glycogen phosphorylase activity in rat liver. Annls Med. exp. Biol. Fenn. 46, 568.

Härkönen, M. H. A., Passonneau, J. V. \& Lowry, O. H. (1969) Relationships between energyreserves and function in rat superior cervical ganglion. $\mathcal{F}$. Neurochem. 16, 1439.

Himwich, H. E. \& NahUm, L. H. (1929) The respiratory quotient of testicle. Am. F. Physiol. 88, 680.

Hollinger, M. A. \& Davis, J. R. (1968) Aerobic metabolism of uniformly labelled $\left[{ }^{14} \mathrm{C}\right]$ glucose in tissue slices of rat testis. F. Reprod. Fert. 17, 343.

Jonge, H. De (1964) Inleiding tot de medische statistiek. Deel II, 2nd edn, p. 486. Verhandeling van het Nederlands Instituut voor Praeventiieve Geneeskunde, Leiden.

Karjalainen, K. \& NuEm, M. (1969) Respiration of the germinal and interstitial cell compartments in the rat testis. Acta endocr. Copenh. Suppl. 138, 245.

Kormano, M. (1967) Development of the rectum-testis temperature difference in the post-natal rat. 7. Reprod. Fert. 14, 427.

Kormano, M. (1968) Penetration of intravenous trypan blue into the rat testis and epididymis. Acta histochem. 30, 133.

Kormano, M., Härkönen, M. \& Kontinen, E. (1964) Effect of experimental cryptorchidism on the histochemically demonstrable dehydrogenases of the rat testis. Endocrinology, 74, 44.

Kuehl, F. A., Patanelil, D. J., Tarnoff, J. \& Humes, J. L. (1970) Testicular adenyl cyclase: Stimulation by the pituitary gonadotrophins. Biol. Reprod. 2, 154.

Lowry, O. H., Passonneau, J. V., Hasselberger, F. X. \& Schulz, D. W. (1964) Effect of ischemia on known substrates and cofactors of the glycolytic pathway in brain. 7. biol. Chem. 239, 18.

Mann, T. (1964) The biochemistry of semen and of the male reproductive tract. Methuen, London. 
Nelson, S., Lowry, O. H. \& Passonneau, J. V. (1966) Changes in energy reserves in mouse brain associated with compressive head injury. In: Head Injury Conference Proceedings, p. 444. Eds. W. P. Caveness and A. E. Walker. Lippincott, Philadelphia.

Niem, M. \& Ixonen, M. (1962) Cytochemistry of oxidative enzyme systems in the Leydig cells of the rat testis and their functional significance. Endocrinology, 70, 167.

Paul, H. E., Paul, M. F., Kopko, F., Bender, R. C. \& EveretT, G. (1953) Carbohydrate metabolism studies on the testis of rats fed certain nitrofurans. Endocrinology, 53, 585.

Rudolph, G. G. \& Olsen, N. S. (1956) Effect of hypophysectomy on dehydrogenase activity of rat tissues. Biochim. biophys. Acta, 19, 382.

Schor, N., Gara, J. \& Perez, A. (1963) Hormonal dependence of oxidative enzymes in the testis of the rat. Nature, Lond. 198, 1310.

SETCHELl, B. P. \& HINKs, N. T. (1967) The importance of glucose in the oxidative metabolism of the testis of the conscious ram and the role of the pentose cycle. Biochem. F. 102, 623.

Setchell, B. P., Voglmayr, J. K. \& Wartes, G. M. H. (1969) A blood-testis barrier restricting passage from blood into rete testis fluid but not into lymph. F. Physiol., Lond. 200, 73.

SETChell, B. P. \& WAITEs, G. M. H. (1964) Blood flow and the uptake of glucose and oxygen in the testis and epididymis of the ram. F. Physiol., Lond. 171, 411.

Setchell, B. P., Waites, G. M. H. \& Thorburn, G. D. (1966) Blood flow in the testis of the conscious ram measured with krypton ${ }^{85}$-effects of heat, catecholamines and acetylcholine. Circulation Res. $18,755$.

Sterngerger, E. \& WAGNer, C. (1961) Observations on the endogenous respiration of rat testicular tissue. Endocrinology, 69, 305.

Tepperman, J., Tepperman, M. H. \& Dick, H. J. (1949) A study of the metabolism of rat testis in vitro. Endocrinology, 45, 491.

VAnDemark, N. L. \& Ewing, L. L. (1963) Factors affecting testicular metabolism and function. I. A simplified perfusion technique for short-term maintenance of rabbit testis. F. Reprod. Fert. 6, 1.

Wattes, G. M. H. \& Setchell, B. P. (1964) Effect of local heating on blood flow and metabolism in the testis of the conscious ram. F. Reprod. Fert. 8, 339. 